\title{
Kerjasama Asean Menangani Kejahatan Lintas Negara : Terorisme \\ Restilia Polii
}

\begin{abstract}
Abstrack
Tulisan ini akan membahas mengenai Kerjasama ASEAN dalam menangani kejahatan lintas Negara, khususnya dalam menangani masalah Terorisme di Asia Tenggara. Melalui literature review ini, penulis menggunakan tiga buku utama sebagai referensi, yang didalamnya terdapat penjelasan mengenai terorisme sebagai bagian dalam kejahatan lintas negara di Asia Tenggara, dan bagaimana kerjasama negara-negara anggota ASEAN menangani isu terorisme ini. Tiga buku tersebut adalah "Hubungan Internasional di Asia Tenggara (Teropong terhadap dinamika, Kondisis riil dan Masa depan)” tulisan Bambang Cipto, "Southeast Asia in Search of an ASEAN Community" tulisan Rudolfo C. Severino, dan "ASEAN dan Tantangan Satu Asia Tenggara” yang disunting Bantarto Bandoro dan Ananta Gondomono. Masing-masing buku terbit pada tahun yang berbeda, dengan penulis yang memiliki pemikiran dan latarbelakang yang berbeda pula.

Tulisan ini dimulai dengan bagian pendahuluan yang menjelaskan secara umum mengenai kerjasama ASEAN dalam menangani kejahatan lintas negara dan terorisme termasuk didalamnya, serta sedikit menyinggung mengenai istilah kejahatan lintas negara (Transnational Crime) dilanjutkan dengan perbandingan dan analisis ketiga buku diatas, dan kemudian kesimpulan. Pada akhirnya tulisan ini bertujuan untuk memahami, membandingkan, dan menganalisis perkembangan kerjasama ASEAN dalam menangani masalah terorisme dari ketiga penulis diatas, dan mencoba melihat kelebihan dan kekurangannya.
\end{abstract}

\section{Pendahuluan}

Perserikatan bangsa-bangsa di Asia Tenggara yang biasanya disebut ASEAN adalah institusi yang terbentuk sejak tahun 1967 yang anggota-anggotanya merupakan negara-negara di kawasan Asia Tenggara. Dan salah satu latar belakang dibentuknya institusi ASEAN ini adalah untuk menjaga stabilitas di kawasan Asia Tenggara dengan melakukan kerjasama politik. Dalam perkembangannya ASEAN melakukan terobosan dengan membentuk Asean Community yang salah satu kerjasamanya dalam bidang keamanan dan pertahanan, 


\section{Global Insigint Journal}

khususnya dalam hal ini kerjasama ASEAN dalam menanggulangi kejahatan lintas negara di kawasan Asia Tenggara. Kemudian dibentuklah pertemuan para menteri pertahanan anggota ASEAN untuk menangani kejahatan lintas-negara ASEAN yang disebut Asean Ministerial Meeting on Transnational Crime (AMMTC) yang pertama kali dibentuk pada tahun 1997, dan bertemu setiap 2 tahun sekali dalam menangani kejahatan lintas negara di kawasan Asia Tenggara ${ }^{1}$. Asean Ministerial Meeting on Transnational Crime ini merupakan badan pengambil keputusan tertinggi dalam kerjasama ASEAN memberantas kejahatan lintas batas (Transnational Crime/TC) dengan mekanisme pertemuan pejabat tingkat tinggi bidang kejahatan lintas negara (Senior Official Meeting on Transnational Crime/SOMTC) sebagai sub-ordinasinya. ${ }^{2}$ Pertemuan dibentuk sebagai upaya menangani kejahatan lintas batas yang mempengaruhi kawasan Asia Tenggara, seperti terorisme, perdagangan narkotika, penyelendupan senjata, pencucian uang, perdagangan manusia dan pembajakan, yang berpotensi untuk mengganggu perdamaian, kemakmuran dan kemajuan ASEAN. ${ }^{3}$ Dalam pertemuan-pertemuan tersebut kemudian disusunlah suatu rencana aksi Asean (Asean Plan of action to combat transnational crime). ${ }^{4}$ Dalam pertemuan-pertemuan tersebut disepakati dibentuknya Sekretariat Kepala Kepolisisan Nasional ASEAN (ASEAN Chiefs of National Police/ASEANAPOL) pada bulan januari 2010 dan Rencana Aksi Komprehensif tentang kontra Terorisme (ASEAN Comprehensive plan of Actionon Counter Terrorism/ACPoA on $\mathrm{CT})^{5}$. Dan terdapat juga pertemuan-pertemuan selanjutnya yang membahas tentang

\footnotetext{
${ }^{1}$ Direktorat Jenderal Kerja Sama ASEAN Kementerian Luar Negeri Indonesia,( 2010), “Asean Selayang Pandang”, (2010), Edisi ke-19, hal.48

${ }^{2}$ Ibid, hal.48-49

${ }^{3}$ Ibid, hal.49

${ }^{4}$ Ibid, hal.49

${ }^{5}$ Ibid
} 
penanganan kejahatan lintas negara ASEAN yang juga bekerjasama dengan negara bukan anggota ASEAN termasuk juga penanganan mengenai terorisme ${ }^{6}$.

Menurut Bambang Cipto, dalam bukunya Hubungan Internasional di Asia Tenggara (Teropong terhadap Dinamika, Realitas, dan Masa Depan) terbitan tahun 2007, khususnya dalam bab yang membahas mengenai Isu-isu keamanan non-tradisonal di Asia Tenggara pasca perang dingin memaparkan bahwa "dewasa ini terjadi perluasan makna keamanan nontradisional yang mencakup bukan hanya keamanan lingkungan dan ekonomi namun juga keamanan manusia yang meliputi organized crime dan trafficking ${ }^{7}$. Organized crime disebut juga transnational Crime, ${ }^{8}$ Jadi dalam buku ini mau memaparkan bahwa istilah keamanan non-tradisional sama dengan kejahatan lintas negara (transnational crime) ${ }^{9}$. Selanjutnya dalam buku ini memaparkan bahwa transnational crime berkembang pesat dengan memburuknya perekonomian ASEAN sebagai akibat dari krisis ekonomi sejak tahun 1998 yang menjadi salah satu alasan mengapa kejahatan semakin marak di kawasan Asia Tenggara. ${ }^{10}$ Dan kejahatan lintas negara di Asia Tenggara pasca perang dingin meliputi Pembajakan, Perdagangan obat-obatan, Penyelundupan dan Perdagangan Manusia, organisasi kejahatan terkemuka di Asia (misalnya Yakusa dari Jepang, dan Triad dari Cina), keamanan Lingkungan, dan Terorisme. ${ }^{11}$

Dibandingkan dengan buku yang berjudul ASEAN dan Tantangan Satu Asia Tenggara terbitan tahun 1997 yang disunting oleh Bantarto Bandoro dan Ananta Gondomono

\footnotetext{
${ }^{6}$ Ibid, hal.49-50

${ }^{7}$ Bambang Cipto, (2007), Hubungan Internasional di Asia Tenggara (Teropong terhadap dinamika, Kondisis riil dan Masa depan), Pustaka Pelajar, cetakan 1, hal. 224

${ }^{8}$ Ibid

${ }^{9}$ Ibid

${ }^{10}$ Bambang Cipto, (2007), Hubungan Internasional di Asia Tenggara (Teropong terhadap dinamika, Kondisis riil dan Masa depan), Pustaka Pelajar, cetakan 1, hal. 225

${ }^{11}$ Ibid, hal. 224-237
} 
dalam bab yang berjudul "ASEAN dan Agenda Keamanan Nonkonvensional"12 yang ditulis Mochtan, jika dianalisis istilah "Keamanan Nonkonvensional" sama dengan istilah "Keamanan Non-Tradisional"13 yang sudah dipaparkan diatas, jadi pada dasarnya keduanya membahas mengenai kejahatan lintas negara di Asia Tenggara, yang juga termasuk didalamnya masalah Terorisme.

Membahas mengenai terorisme, penulis menemukan kompleksitas dalam mengartikan terorisme itu sendiri, karena terdapat beberapa perbedaan pemahaman mengenai arti dari kata "Terorisme". Dalam kamus Bahasa Indonesia mengartikan kata terorisme sebagai "Penggunaan kekerasan untuk menciptakan ketakutan dalam usaha mencapai tujuan"14 dan kata teroris sebagai "Orang tau golongan yang berbuat kejam dan menimbulkan ketakutan"15. Dalam tulisan ini tidak akan membahas lebih jauh mengenai pemahaman kata "Terorisme" bagi setiap individu, state, regional, maupun dunia internasional, tetapi akan fokus pada bagaimana peran ASEAN dalam menangani Terorisme di Asia Tenggara sendiri.

Terorisme menjadi penting sejak terjadinya peristiwa sebelas September $2001 \mathrm{di}$ Amerika Serikat. ${ }^{16}$ Kampanye anti-terorisme yang dilancarkan Presiden Bush telah menjadikan Asia Tenggara sebagai "front kedua" setelah Afganistan ${ }^{17}$. Asia Tenggara menjadi target kampanye karena dua hal : Yang pertama, karena mayoritas penduduk dikawasan ini beragama Islam, yakni Agama yang sama dengan Osama Bin Laden yang dituduh AS berada dibalik serangan di New York dan Washington D.C. pada 11 september

\footnotetext{
${ }^{12}$ Bandoro, B\&Gondomono (Ed.), A (1997),"ASEAN dan Tantangan Satu Asia Tenggara”, CSIS, Jakarta, hal. $46-57$

${ }^{13}$ Ibid

${ }^{14}$ Tim Reality, (2008), Kamus Terbaru Bahasa Indonesia, Reality Publisher, Cetakan 1, hal. 634

${ }^{15}$ Ibid

${ }^{16}$ Bambang Cipto, (2007), Hubungan Internasional di Asia Tenggara (Teropong terhadap dinamika, Kondisis riil dan Masa depan), Pustaka Pelajar, cetakan 1, hal. 237

${ }^{17}$ Ibid
} 


\section{Global Insigint Journal}

2001. ${ }^{18}$ Kedua, karena dikawasan ini memang terdapat beberapa kelompok minoritas Islam yang cenderung keras dalam menyampaikan aspirasi mereka yang tersebar di Indonesia, Malaysia, dan Philipina. ${ }^{19}$ Tuduhan-tuduhan ini tidak mudah diterima oleh pemerintahpemerintah di Asia Tenggara dan para pengamat yang sudah cukup lama memahami Asia Tenggara $^{20}$. Alan Collin ${ }^{21}$, misalnya, menanggapi tuduhan pemerintahan Bush ini sebagai pernyataan yang salah. ${ }^{22}$

ASEAN secara bertahap menanggapi isu terorisme ini melalui serangkaian pertemuan dalam forum-forum resminya ${ }^{23}$. Dua bulan setelah peristiwa $11 / 9$ dalam pertemuan puncak ASEAN ketujuh di Brunei Darusalam ASEAN mendeklarasikan tindakan bersama untuk menanggulangi terorisme ${ }^{24}$. Secara kelembagaan ASEAN terus melakukan upaya untuk memerangi terorisme ${ }^{25}$. ASEAN Ministerial Meeting on Transnasional Crime (AMMTC) adalah media yang paling penting bagi ASEAN dalam menanggapi isu terorisme ${ }^{26}$.

\section{Perbandingan dan Analisis}

Buku pertama yang akan dianalisis yaitu yang ditulis oleh Dr. Bambang Cipto. MA yang berjudul, "Hubungan Internasional di Asia Tenggara : Teropong terhadap Dinamika, Realitas dan Masa Depan”, terbitan tahun 2007 yang salah satu babnya menjelaskan tentang Isu-Isu Keamanan non-tradisional di Asia Tenggara Pasca Perang Dingin, yang dalam subbabnya menjelaskan mengenai isu Terorisme. Dalam tulisannya memaparkan secara eksplisit

\footnotetext{
${ }^{18}$ Ibid

${ }^{19}$ Ibid

${ }^{20}$ Collins, Alan. Security and Southeast Asia : Domestik, Regional, and Global Issues, Singapore: Institute of Southeast Asian Studies, 2003

${ }^{21}$ Bambang Cipto, (2007), Hubungan Internasional di Asia Tenggara (Teropong terhadap dinamika, Kondisis riil dan Masa depan), Pustaka Pelajar, cetakan 1, hal. 237

${ }^{22}$ Ibid

${ }^{23}$ Ibid, hal. 239

${ }^{24}$ Ibid

${ }^{25}$ Ibid

${ }^{26}$ Ibid, hal. 240
} 
permulaan pemerintah-pemerintah di Asia Tenggara bekerjasama menangani isu terorisme ${ }^{27}$. secara histori mulanya akibat dari tuduhan-tuduhan Amerika Serikat yang pada saat itu masa pemerintahan Presiden Bush pasca peristiwa 11 september 2001 yang sedang gencargencarnya melakukan kampanye anti terorisme, dan menjadikan kawasan Asia Tenggara sebagai "front kedua" setelah Afganistan ${ }^{28}$. Yang jika dijelaskan secara sederhana karena mayoritas Negara-negara di Asia Tenggara beragama Islam, yaitu Agama yang sama dengan Osama Bin Laden yang dituduh AS berada dibalik serangan New York dan Washigton D.C 11 september $2001 .^{29}$ Setelah membaca buku ini menghasilkan suatu analisa bahwa tuduhantuduhan itulah yang awalnya memacu ASEAN melakukan kerjasama untuk menangani masalah terorisme. Jadi secara implisit dalam buku ini khususnya dalam sub-bab mengenai terorisme, latar belakang awalnya ASEAN melakukan kerjasama dalam memberantas Terorisme adalah karena tuduhan-tuduhan dari Amerika Serikat seperti yang sudah dipaparkan diatas, dan ASEAN tidak mau wilayahnya terlalu dicampuri oleh AS dalam hal keamanan dan Pertahanan, dan dalam hal ini mengenai isu Terorisme ${ }^{30}$. Yang menarik disini, meskipun terlihat merespon Ajakan AS untuk memerangi Terorisme dengan di deklarasikannya tindakan bersama untuk menanggulangi terorisme setelah dua bulan peristiwa 11 september $2001^{31}$, meskipun demikian, tidak semua negara anggota ASEAN mendukung penuh ajakan AS untuk memerangi Afganistan ${ }^{32}$. Perdana Menteri Malaysia yang paling keras menyatakan penolakannya memerangi Afganistan ${ }^{33}$.

\footnotetext{
${ }^{27}$ Ibid, hal. 237

${ }^{28}$ Ibid

${ }^{29}$ Ibid

${ }^{30}$ Ibid, hal. 237-241

${ }^{31}$ Ibid, hal.239

${ }^{32}$ Ibid

${ }^{33}$ Ibid (Collins, Alan. Security and Southeast Asia : Domestik, Regional, and Global Issues, Singapore: Institute of Southeast Asian Studies, 2003 )
} 


\section{Global Insigiht Journal}

Meskipun akhirnya kerjasama ASEAN memerangi terorisme hingga saat ini terus berkembang, tetapi berdasarkan analisis, dalam buku ini jelas mau menjelaskan bahwa permulaan kerjasama ASEAN menangani masalah terorisme adalah karena tidak terima dengan segala tuduhan AS dalam kampanyenya anti terorisme, dan tidak mau AS campur tangan dalam hal keamanan di Asia Tenggara, khususnya dalam hal ini masalah terorisme. Hal ini juga didukung karena saat itu (tahun 2001) belum gencarnya serangan teroris di Asia Tenggara khususnya Indonesia, yang baru mulai merasakan serangan teroris sejak terjadinya Bom Bali tahun 2002. Penulis buku inipun merupakan dosen jurusan Hubungan Internasional di salah satu Universitas di Indonesia, yang juga pernah menulis tentang "Tekanan Amerika terhadap Indonesia"34. Jadi secara sederhana bisa disimpulkan bahwa penulis ini juga mengetahui banyak mengenai Amerika Serikat dan tidak terlalu suka dengan kekuasaan negara yang biasa disebut negara super power tersebut. Selanjutnya, meskipun buku ini diluncurkan pada tahun 2007, dalam sub-babnya mengenai Terorisme, penulis buku ini hanya membahas soal Latar belakang atau permulaan mengapa institusi ASEAN berinisiatif untuk bekerjasama memberantas Terorisme. Bahkan dalam akhir penulisannya mengenai Terorisme, secara implisit mau memaparkan bahwa ASEAN tidak terlalu tertarik terhadap isu-isu teorisme, dengan pernyataannya bahwa "Pada pertengahan tahun 2006 semakin mengurangi semangat negara-negara ASEAN terhadap isu Terorisme",35. Jadi intinya berdasarkan analisis, meskipun buku ini diterbitkan tahun 2007, setelah beberapa pemboman di Indonesia, dan meskipun sudah sejak tahun 1997 sudah diadakan pertemuan setiap dua tahun sekali dalam pertemuan para menteri yang membahas mengenai kajahatan lintas negara dalam ASEAN Ministerial Meeting on Transnational Crime/AMMTC, penulis tetap menganggap ASEAN belum terlalu fokus dan tertarik dengan isu Terorisme di Asia

\footnotetext{
${ }^{34}$ Ibid, hal. 277

${ }^{35}$ Ibid, hal. 241
} 
Tenggara. Karena memang bahasan mengenai ini hanya fokus pada latar belakang Asean mengadakan kerjasama penanganan terorisme pasca 11 september 2001.

Buku kedua dari Rudolf C. Severino yang berjudul Southeast Asia In Search of a ASEAN Community, yang terbit pada tahun 2006 dalam babying berjudul Regional Security: The Asean Role dan sub-babnya International Terorism, menjelaskan bahwa ASEAN harus bersama-sama memberantas terorisme pasca serangan 11 september 2001 di Amerika Serikat $^{36}$. Karena Terorisme juga merupakan salah satu bagian dari kejahatan lintas negara yang sudah sejak tahun 1997 dibahas dalam pertemuan para menteri yang menangani kejahatan lintas negara ASEAN $^{37}$. Dalam buku ini secaraimplisit mau memaparkan bahwa ASEAN wajib bekerjasama dengan negara-negara lain, khususnya dengan Amerika Serikat dalam memberantas Terorisme. Jelas penulis buku ini ingin menekankan bahwa terorisme merupakan suatu jaringan intenasional, dan setiap negara wajib untuk bekerjasama menanganinya, termasuk ASEAN. Berdasarkan analisis penulis, karena buku ini ditulis oleh orang yang berwarganegara Singapura yang notabene Singapura memang memiliki hubungan yang dekat dengan Amerika Serikat, sehingga jika dianalisis, dalam tulisannya mengarahkan bahwa ASEAN harus bekerjasama dengan AS dalam memberantas Terorisme. Masih dalam buku yang sama, dalam bab berikutnya juga mengenai The Asean Community : It is for real? Dan sub-babnya yang berjudul Terrorism and Transnational Crime menekankan bahwa untuk menangani masalah terorisme bukan hanya sebatas perencanaan dan pertemuanpertemuan saja, tetapi juga harus ada aksi dan tindakan yang nyata dari institusi ASEAN $\mathrm{ini}^{38}$.

\footnotetext{
${ }^{36}$ Severino, Rudolfo C.,(2006), Southeast Asia in Search of an ASEAN Community: Insights from the former ASEAN Secretary-General, ISEAS, Singapore, hal. 198

${ }^{37}$ Ibid

${ }^{38}$ Ibid, hal.364
} 


\section{Global Insigiht Journal}

Buku ketiga berjudul ASEAN dan Tantangan Satu Asia Tenggara yang disunting Bantarto Bandoro dan Ananta Gondomono, terbitan tahun 1997 dalam bab yang berjudul "ASEAN dan agenda Keamanan Nonkonvensional" yang ditulis oleh A.K.P Moctan, membahas mengenai kesiapan ASEAN dalam menghadapi keamanan nonkonvensional ${ }^{39}$. Menurut Moctan, masalah keamanan konvensional (kejahatan lintas negara) akan menjadi tantangan besar bagi perkembangan ASEAN di masa mendatang ${ }^{40}$. Hal ini disebabkan oleh beberapa faktor; pertama, hakekat dari masalah keamanan nonkonvensional yaitu sukar untuk dirumuskan, bahkan sering muncul sebagai masalah "baru" ${ }^{41}$. Factor kedua yang merumitkan penanganan masalah keamanan nonkonvensional adalah kecenderungan sebagai isu lintas negara $^{42}$. Dan salah satu masalah nonkonvensional yang akan dihadapi oleh ASEAN pada masa yang akan datang adalah "Terorisme" penulis karena buku ini merupakan buku terbitan tahun 1997 yang pada saat itu belum muncul masalah-masalah yang berhubungan dengan terorisme di negara-negara anggota ASEAN, Jadi saat itu masih lebih fokus dengan masalah perekonomian. Walaupun masalah terorisme ini masih merupakan prediksi dalam keamanan nonkonvensional, tetapi berdasarkan analisis, dalam buku ini penulis cenderung bersikap pesimistis bahwa ketika akan menghadapi masalah Terorisme maupun keamanan nonkonvensional lainnya, ASEAN belum terlalu siap ${ }^{44}$. Alasannya sangat jelas dengan pernyataan penulis bahwa sampai pada tahun 1997 itu "ASEAN masih lebih bersikap reaktif daripada antisipatif" 45 Kesiapan ASEAN untuk mengantisipasi terorisme belum diketahui. Jadi dalam buku ketiga ini

\footnotetext{
${ }^{39}$ Bandoro, B\&Gondomono (Ed). (1997),"ASEAN dan Tantangan Satu Asia Tenggara", (Jakarta: CSIS), hal. $46-57$

${ }^{40}$ Ibid, hal. 46

${ }^{41}$ Ibid

${ }^{42}$ Ibid

${ }^{43}$ Ibid, hal. 49

${ }^{44}$ Ibid, hal. 52

${ }^{45}$ Ibid
} 


\section{Global Insigiht Journal}

berdasarkan hasil analisa, seperti yang sudah dipaparkan diatas, kesiapan ASEAN dalam menangani kasus Terorisme di Asia Tenggara masih dipertanyakan, bahkan masih sangat terlihat sikap pesimistis dalam penulisan buku tersebut. Yang menjadi point penting dalam buku ketiga ini adalah penulis memberikan suatu solusi konkrit untuk ASEAN bahwa dalam menangani keamanan nonkonvensional yang termasuk didalamnya isu terorisme harus dengan meningkatkan koordinasi antar negara anggota ASEAN, yang sampai saat ini masih terus dilakukan oleh ASEAN, salah satu contohnya adalah pelaksanaan AMMTC sejak tahun 1997, yang sampai saat ini terus dilakukan dua tahun sekali.

Berdasarkan analisis, isi dari ketiga buku yang sudah dipaparkan diatas memiliki fokus dan tujuan penulisan yang berbeda-beda. Buku pertama hanya menjelaskan tentang latar belakang ASEAN melakukan kerjasama menangani masalah terorisme, dan menurut kacamata penulis buku tersebut hanya karena sekedar tidak terima dengan tuduhan-tuduhan AS karena anggota ASEAN mayoritas beragama Islam, dan karena tidak mau AS mencampuri masalah keamanan Asia Tenggara. Buku kedua, sebaliknya memaparkan bahwa dengan ASEAN bekerjasama dengan negara lain, khususnya Amerika Serikat akan sangat membantu dalam menangani masalah terorisme di Asia Tenggara. Kedua buku ini hanya berbeda 1 tahun dalam penerbitan, buku pertama tahun 2007, buku kedua tahun 2006. Yang sedikit jauh penerbitannya adalah buku ketiga, yaitu penerbitannya tahun 1997. Yang pada saat itu di Asia Tenggara masih fokus dengan perbaikan perekonomian daripada maslah terorisme yang belum terlalu banyak dibicarakan. Tetapi penulis yang ketiga sudah memproyeksikan bahwa tantangan ASEAN di masa mendatang salah satunya adlah masalah Terorisme. Dan berdasarkan pengamatan penulis saat itu, jika nanti diperhadapkan dengan maslah Terorisme nanti, ASEAN belum akan siap. Jadi dalam hal ini terlihat jelas sikap pesimistis terhadap ASEAN. 


\section{Global Insigint Journal}

Dalam perkembangannya, kerjasama ASEAN menangani kejahatan lintas negara khususnya masalah terorisme, setelah semakin maraknya aksi terorisme di kawasan Asia Tenggara sejak tahun 2002, ASEAN bukan hanya melakukan sekedar pertemuan para menteri pertahanan ASEAN setiap dua tahun sekali semenjak tahun 1997 (ASEAN Ministerial Meeting on Transnational Crime/AMMTC), ${ }^{46}$ disusunnya ASEAN Plan of Action to combat Transnational Crime, dibentuknya kepala kepolisian nasional ASEAN, ${ }^{47}$ Rencana Aksi Komprehensif tentang kontra Terorisme, ${ }^{48}$ dan berbagai bentuk pertemuan lainnya yang membahas tentang kerjasama lintas negara ASEAN khususnya dalam hal ini masalah terorisme sudah mulai menunjukkan kemajuan, karena dalam pertemuan-pertemuan tersebut sudah terciptanya rencana-rencana konkrit yang akan dilakukan mengenai masalah terorisme. Contohnya tahun 2011 negara-negara anggota ASEAN sepakat saling berbagi data intelejen $^{49}$, pada tahun yang sama juga terdapat pernyataan dari Badan Nasional Penanggulangan Terorisme bahwa kerjasama terorisme ASEAN paling nyata karena kerjasama itu terjadi hingga pada tataran operasional ${ }^{50}$. Selanjutnya pada tahun 2013 ini Menteri Pertahanan se-ASEAN ditambah 8 negara sahabat akan menggelar pertemuan guna latihan bersama melawan terorisme. ${ }^{51}$

Walaupun kemajuan kerjasama ASEAN dalam menangani terorisme yang dimaksud diatas belum terlalu memberikan dampak yang signifikan khususnya bagi Indonesia sendiri yang sudah beberapa kali merasakan serangan terorisme, berturut-turut dari tahun 2002-2005 yang membuat ketakutan bagi warga negara sendiri, tapi dalam tulisan ini tetap saja optimis,

\footnotetext{
46 Direktorat Jenderal Kerja Sama ASEAN Kementerian Luar Negeri Indonesia,( 2010), “Asean Selayang Pandang", (2010), Edisi ke-19, hal.48

${ }^{47}$ Ibid, hal.49

${ }^{48}$ Ibid

${ }^{49}$ Diakses dari www.suarapembaruan.com pada tanggal 8 Maret 2013

${ }^{50}$ Diakses dari www.suaramerdeka.com pada tanggal 8 Maret 2013

${ }^{51}$ Diakses dari www.detinews.com pada tanggal 8 Maret 2013
} 


\section{Global Insigiht Journal}

dengan didukung beberapa data diatas yang dari tahun 2011 sampai saat ini, sudah ada langkah-langkah konkrit yang disepakati negara-negara anggota ASEAN dalam menangani masalah terorisme di region Asia Tenggara. Dari sikap optimisme tersebut, dalam mengakhiri tulisan ini, memunculkan proyeksi ke depan bahwa kerjasama ASEAN dalam menangani Terorisme akan sangat membantu dalam mengatasi masalah terorisme di region Asia Tenggara.

\section{Kesimpulan}

Dari ulasan diatas dapat disimpulkan bahwa tiga buku dari era yang berbeda, para penulis dari kebangsaan yang berbeda, budaya dan pendidikan yang berbeda, juga akan menghasilkan suatu analisis sampai pada hasil penulisan yang berbeda juga, walaupun membahas topik yang sama. Pastinya akan memiliki fokus dan tujuan penulisan yang berbeda.

Buku pertama hanya menjelaskan tentang latar belakang ASEAN melakukan kerjasama menangani masalah terorisme, dan menurut kacamatanya hanya karena sekedar tidak terima dengan tuduhan-tuduhan AS karena anggota ASEAN mayoritas beragama Islam, dan karena tidak mau AS mencampuri masalah keamanan Asia Tenggara. Buku kedua, sebaliknya memaparkan bahwa dengan ASEAN bekerjasama dengan negara lain, khususnya Amerika Serikat akan sangat membantu dalam menangani masalah terorisme di Asia Tenggara. Kedua buku ini hanya berbeda 1 tahun dalam penerbitan, buku pertama tahun 2007, buku kedua tahun 2006. Yang sedikit jauh penerbitannya adalah buku ketiga, yaitu penerbitannya tahun 1997. Yang pada saat itu di Asia Tenggara masih fokus dengan perbaikan perekonomian daripada maslah terorisme yang belum terlalu banyak dibicarakan. Tetapi penulis yang ketiga sudah memproyeksikan bahwa tantangan ASEAN di masa mendatang salah satunya adlah masalah Terorisme. Dan berdasarkan pengamatan penulis saat 


\section{Global Insigiht Journal}

itu, jika nanti diperhadapkan dengan maslah Terorisme nanti, ASEAN belum akan siap. Jadi dalam hal ini terlihat jelas sikap pesimistis terhadap ASEAN.

Tetapi seperti yang sudah dipaparkan diatas pada akhirnya penulisan ini akan tetap bersikap optimis dengan kerjasama ASEAN menangani masalah terorisme. optimisme ini muncul karena berdasarkan data yang juga sudah dipaparkan diatas, sejak tahun 2011 sudah ada langkah-langkah konkrit dalam mengatasi masalah terorisme diregion Asia Tenggara. Sekali lagi ini berbicara mengenai proses, karena menangani masalah yang serius seperti terorisme ini tidak akan bisa teratasi begitu saja, karena dalam hal ini berbicara mengenai jaringan. Jadi pada dasarnya membutuhkan waktu dalam mengatasi jaringan terorisme ini. yang pasti, langkah konkrit sudah dilakukan ASEAN, dan untuk kedepannya tinggal mengevaluasi hasil kerjasama ini, demi terus menjaga keamanan dan kestabilan negaranegara ASEAN.

\section{Daftar Pustaka}

Bambang Cipto, (2007), Hubungan Internasional di Asia Tenggara (Teropong terhadap dinamika, Kondisis riil dan Masa depan), Pustaka Pelajar, cetakan 1.

Bandoro, B\&Gondomono (Ed). (1997),"ASEAN dan Tantangan Satu Asia Tenggara".

Collins, Alan. Security and Southeast Asia : Domestik, Regional, and Global Issues, Singapore: Institute of Southeast Asian Studies, 2003.

Direktorat Jenderal Kerja Sama ASEAN Kementerian Luar Negeri Indonesia,( 2010), “Asean Selayang Pandang”, (2010), Edisi ke-19.

Severino, Rudolfo C.,(2006), Southeast Asia in Search of an ASEAN Community: Insights from the former ASEAN Secretary-General, ISEAS, Singapore. 


\begin{tabular}{|r|r|}
\hline Gobal Insigint Journal & Vol 03, No. 01 \\
Oktober - Maret 2018 \\
ISSN 2541-318X \\
\hline
\end{tabular}

Reality, (2008), Kamus Terbaru Bahasa Indonesia, Reality Publisher, Cetakan 1. 